\title{
THE CHURCH HYMN “CHRIST RECEIVETH SINFUL MEN": ITS RELATIONSHIP TO THE GERMAN ORIGINAL AND ITS ADAPTATION BY AMERICAN AND KOREAN HYMNALS
}

\author{
UDC $783=30$
}

\author{
Sa Ra Park \\ Texas State University - School of Music, San Marcos, Texas, USA
}

\begin{abstract}
In the $19^{\text {th }}$ century, German Protestant hymns were translated into English and have been sung in its language area. By evangelizing Korea, Western - including some German - church hymns were introduced. However, it is noticeable that content as well as linguistic and musical differences between the German and Korean versions could occur in the translation process. This paper examines one particular church hymn, namely "Christ Receiveth Sinful Men", that was included in the Korean hymnals at the end of the $19^{\text {th }}$ century. This church hymn has an interesting history; its text is originally from Germany, whereby the origin of the music is the United States. This paper explores the questions of how the text and the music were combined and how changes took place in their transmission. Methodologically, sources were compared that were relevant at the time of adaption. The intercultural relationships between the hymns of other countries would be of interest not only to hymnological scholars, but also to missiologists and musicologists, as well as church musicians.
\end{abstract}

Key words: Jesus nimmt die Sünder an, Christ Receiveth Sinful Men, Erdmann Neumeister, James McGranahan, Evangelisches Gesangbuch of 1993, 21 st Century Hymnal of 2006

\section{INTRODUCTION}

The church hymn "Christ Receiveth Sinful Men" is still sung by American Christians; for example, it is contained in the Baptist Hymnal of 2008. Its music was composed by American musician and composer James McGranahan (1840-1907), and the lyrics were written by a German pastor named Erdmann Neumeister (1671-1756). It is interesting to observe that this combination of text and music is not known by German Christians. In

Received November 30, 2020 / Accepted April 9, 2021

Corresponding author: Sa Ra Park

Texas State University - School of Music

601 University Dr., San Marcos, Texas 78666, USA

E-mail: srpark146@gmail.com 
the current German hymnal Evangelisches Gesangbuch of 1993, the text of Neumeister Jesus nimmt die Sünder an is set to another melody. Moreover, we can find that there are differences between the lyrics in the German and American versions. Furthermore, it is noteworthy that this hymn is known to Korean Christians since its inclusion in the Korean hymnal at the end of the $19^{\text {th }}$ century. The current Korean hymnal 21 st Century Hymnal of 2006 contains it as the American version, but not as the German one.

This paper will show how the lyrics of Neumeister are altered by McGranahan, and the aspects that played an important role in the reception of the hymn in the United States and in Korea. This topic has not been explored in scholarly research; this is an original study and it is based on primary sources such as Evangelisches Gesangbuch of 1993, Songs of Eternal Life of [1858], Gospel Hymns Nos. 1 to 6 of 1895, and 21 ${ }^{\text {st }}$ Century Hymnal of 2006.

\section{TEXT}

The text of Jesus nimmt die Sünder an, which is contained in the Evangelisches Gesangbuch of 1993 under the number 353, was penned by Erdmann Neumeister. ${ }^{1}$ To be able to sing with the congregation after his sermon, Neumeister, who was the pastor at St. Jakobi in Hamburg, wrote numerous church hymn lyrics that related to the Sunday scripture readings and his sermons (Die Lieder unserer Kirche 1958, 419; Liederkunde 1990, 234; Thust 2015, 166). In 1718, he wrote the text Jesus nimmt die Sünder an, which was based on the Gospel for the third Sunday after Trinity, Luke 15:1-10. This Bible passage is about the parables of the lost sheep and of the lost coin. In the same year, the author had a song collection printed for his congregation: "Evangelical Resonance, That Is: New Spiritual Songs Over the Orderly Gospels of Sundays and Special Days for the Whole Year."2 This collection contained this particular text.

During the $19^{\text {th }}$ century, Neumeister's text was translated into English quite a few times (Dictionary of Hymnology 1985, 797-798). Among the translations, Emma F. Bevans' ${ }^{3}$ Sinners Jesus will receive was the direct source for the Korean hymn book. Her translation was close to the original. This can primarily be seen in the fact that she translated all stanzas with six lines each (Songs of Eternal Life, [1858], 23-25). In contrast, Neumeister's text was often shortened in English and American hymnals, although these had Bevan's translation as a source (Dictionary of Hymnology 1985, 797).

\footnotetext{
${ }^{1}$ Erdmann Neumeister (1671-1756) was born in 1671 at Uichteritz near Weißenfels. After studying in Leipzig, he worked in Bad Bibra and Eckartsberga as a pastor and in Weißenfels as a court chaplain. In 1706, he came to Sorau in the Lower Lusatia, where he worked as a senior court pastor and superintendent. Since 1715, he was a senior pastor at St. Jakobi in Hamburg. He wrote more than 700 church hymn texts that related to the Sunday scripture readings and to his sermons, and he wrote numerous cantata texts for five ecclesiastical years that were set to music by his friend Georg Philipp Telemann and by Johann Sebastian Bach. He advocated for introducing the cantata into the Protestant church service (Evangelisches Gesangbuch 1994, No. 957; Die Lieder unserer Kirche 1958, 419; Thust 2015, 166).

2 "Evangelischer Nachklang, das ist: Neue geistreiche Gesänge über die ordentlichen Sonn- und Festtagsevangelia aufs ganze Jahr" (Liederkunde 1990, 234).

${ }^{3}$ Emma Frances Bevan (1827-1909) was born in 1827 in Oxford. Her father Philip Nicholas Shuttleworth was a pastor and Warden at New College, Oxford, and later bishop in Chichester. In 1858, she published the collection Songs of Eternal Life, which contained her English translations of German church hymns. One year later, she edited Songs of Praise for Christian Pilgrims (Mearns 1985, 139).
} 
By the end of the $19^{\text {th }}$ century, Bevan's translation was combined with James McGranahans' melody, ${ }^{4}$ therefore the text was arranged corresponding to the melody. This new arrangement first appeared in the men's choir collection The Gospel Male Choir, vol. 2, which was published in 1883 by McGranahan (Cho 1996, 113; Moon and Na 2012, 444; Oh 2015, 888). He then included this song in his 1894 edited song collection Gospel Hymns Nos. 1 to 6 Completed, under the number 331 (Cho 1995, 259). In the following table, Bevan's version (Songs of Eternal Life [1858], 23-25) and the arranged text by McGranahan (Gospel Hymns Nos. 1 to 6, 1895, No. 331) are compared in order to show how McGranahan changed the text for his music.

Table 1 Comparison of the Version by Bevan and the Arranged Text by McGranahan

\begin{tabular}{|c|c|c|c|}
\hline Stanza & Bevans Translation & Stanza & The Arranged Text by McGranahan \\
\hline 1 & $\begin{array}{l}\text { Sinners Jesus will receive, } \\
\text { Say this word of grace to all, } \\
\text { Who the heavenly pathway leave, } \\
\text { All who linger, all who fall! } \\
\text { This can bring them back again, } \\
\text { Christ receiveth sinful men. }\end{array}$ & 1 & $\begin{array}{l}\text { Sinners Jesus will receive: } \\
\text { Sound this word of grace to all } \\
\text { Who the heav'nly pathway leave, } \\
\text { All who linger, all who fall. } \\
\text { [Refrain] } \\
\text { Sing it o'er and o'er again: } \\
\text { Christ receiveth sinful men; } \\
\text { Make the message clear and plain: } \\
\text { Christ receiveth sinful men. }\end{array}$ \\
\hline 2 & $\begin{array}{l}\text { We deserve no help, no love, } \\
\text { Yet His changeless word is given, } \\
\text { That His grace shall not remove: } \\
\text { No man at the gate of Heaven } \\
\text { In His name shall knock in vain } \\
\text { Christ receiveth sinful men. }\end{array}$ & & \\
\hline 3 & $\begin{array}{l}\text { Shepherds seek their wandering sheep } \\
\text { O'er the mountains bleak and cold, } \\
\text { Jesus such a watch doth keep } \\
\text { O'er the lost ones of His fold; } \\
\text { Seeking them o'er moor and fen: } \\
\text { Christ receiveth sinful men. }\end{array}$ & & \\
\hline 4 & $\begin{array}{l}\text { Come, and He will give you rest, } \\
\text { Sorrow-stricken, sin-defiled } \\
\text { He can make the sinfullest } \\
\text { God the Father's blessed child: } \\
\text { Trust Him, for His word is plain, } \\
\text { Christ receiveth sinful men. }\end{array}$ & 2 & $\begin{array}{l}\text { Come, and He will give you rest; } \\
\text { Trust Him, for His word is plain; } \\
\text { He will take the sinfulest; } \\
\text { Christ receiveth sinful men. } \\
\text { [Refrain] } \\
\text { Sing it o'er and o'er again: } \\
\text { Christ receiveth sinful men; } \\
\text { Make the message clear and plain: } \\
\text { Christ receiveth sinful men. }\end{array}$ \\
\hline
\end{tabular}

\footnotetext{
${ }^{4}$ Despite paternal resistance, James McGranahan (1840-1907) studied music and worked as music teacher, music director, and choir conductor. After the death of Philip Paul Bliss (1838-1876), McGranahan committed himself as a musician to Revivalism, while he worked with the evangelist Daniel Webster Whittle (1840-1901) in England and in the United States. He composed many songs for Sunday schools as well as gospel songs. He published many hymn books, among them the successful series Gospel Hymns. In the 21st Century Hymnal of 2006, six of his songs are contained; three of those lyrics originated from Whittle (Cho 2007, 288; Moon and Na 2012, 431; Oh 2015, 575; Wilhoit 2013, 302-303).
} 


\begin{tabular}{|c|c|c|c|}
\hline 5 & $\begin{array}{l}\text { Sick, and sorrowful, and blind, } \\
\text { I with all my sins draw nigh, } \\
\text { O my Saviour, Thou canst find } \\
\text { Help for sinners such as I. } \\
\text { Speak that word of love again: } \\
\text { Christ receiveth sinful men. }\end{array}$ & & \\
\hline 6 & $\begin{array}{l}\text { Yea, my soul is comforted, } \\
\text { For Thy Blood hath washed away } \\
\text { All my sins, though crimson-red, } \\
\text { And I stand in white array, } \\
\text { Purged from every spot and stain: } \\
\text { Christ receiveth sinful men. }\end{array}$ & & \\
\hline 7 & $\begin{array}{l}\text { Now my heart condemns me not, } \\
\text { Pure before the Law I stand; } \\
\text { He who cleansed me from all spot, } \\
\text { Satisfied its last demand. } \\
\text { Who shall dare accuse me then? } \\
\text { Christ receiveth sinful men. }\end{array}$ & 3 & $\begin{array}{l}\text { Now my heart condemns me not, } \\
\text { Pure before the law I stand; } \\
\text { He who cleansed me from all spot, } \\
\text { Satisfied its last demand. } \\
\text { [Refrain] } \\
\text { Sing it o'er and o'er again: } \\
\text { Christ receiveth sinful men; } \\
\text { Make the message clear and plain: } \\
\text { Christ receiveth sinful men. }\end{array}$ \\
\hline 8 & $\begin{array}{l}\text { Christ receiveth sinful men } \\
\text { Even me with all my sin; } \\
\text { Openeth to me Heaven again, } \\
\text { With Him I may enter in. } \\
\text { Death hath no more sting nor pain, } \\
\text { Christ receiveth sinful men. }\end{array}$ & 4 & $\begin{array}{l}\text { Christ receiveth sinful men, } \\
\text { Even me with all my sin; } \\
\text { Purged from ev-'ry spot and stain, } \\
\text { Heav'n with Him I enter in. } \\
\text { [Refrain] } \\
\text { Sing it o'er and o'er again: } \\
\text { Christ receiveth sinful men; } \\
\text { Make the message clear and plain: } \\
\text { Christ receiveth sinful men. }\end{array}$ \\
\hline
\end{tabular}

As can be clearly seen from this table, the original text was reduced by half. It is striking that the third stanza of the German text or the English version by Bevan was not included in the arranged text by McGranahan. This stanza is about the lost sheep, whose image Neumeister used as basis. McGranahan interpreted it in a different context: Matthew 9:9-13. The proof is the Bible passage that is indicated in the Gospel Hymns Nos. 1 to 6 Completed of 1894 under the title Christ Receiveth Sinful Men (No. 331): "They that are whole need not a physician, but they that are sick" (Matthew 9:12).

As shown in the refrain "Sing it o'er and o'er again: Christ receiveth sinful men; Make the message clear and plain: Christ receiveth sinful men.”, the emotion 'joy' stands in the arranged text by McGranahan in the foreground. This is different from the one of Neumeister. The Handbuch zum Evangelischen Kirchengesangbuch comments on his text Sinners Jesus will receive as follows: "The word 'sorrow' is used in this hymn twice, but the word 'joy' doesn't appear, whereas the parables in Luke 15 cannot do enough to describe the great 'joy before the angels of God'!"5

\footnotetext{
5 “'Zwar fällt das Wort 'Betrübte' in diesem Liede zweimal, das Wort 'Freude' aber kommt nicht vor, während doch die Gleichnisse Luk. 15 sich gar nicht genug darin tun können, die große 'Freude vor den Engeln Gottes' zu beschreiben!" (Liederkunde 1990, 235.)
} 


\section{MELODY}

Johann Ulich (1634-1712) ${ }^{6}$ composed the melody, which is set to Neumeister's text in the Evangelisches Gesangbuch of 1993, No. 353. However, it is not quite sure whether this combination already occurred at that time (Thust 2015, 167). Ulich's melody appeared for the first time in the collection Siebenfache Welt- und Himmels-Kapell [Sevenfold Worldand Heaven-Chapel], which was published in 1674 by the Lutheran theologian Michael Schernack (1622-1675). There, this melody was set to the text Meinen Jesus la $\beta$ ich nicht by Christian Keimann (1607-1662), which is well-known through the chorale cantata by Max Reger (ibid., 279). ${ }^{7}$ It is interesting to observe that the two texts are characterized by calmness and earnest: Keimann's text is about a personal love toward Jesus Christ and Neumeister's text about Jesus' love for the sinners. Corresponding to this calm atmosphere, the melody moves mostly stepwise in a smaller ambitus F4-D5 (see Example 1). Furthermore, the tone repetitions, which occur in upbeat of each line, are supporting the calm character of the melody. As far as the rhythm is concerned, the quarter notes are mainly used, which makes the music steady. These musical characteristics are adequate to Neumeister's text, in which the emotion 'sorrow' is in the foreground.

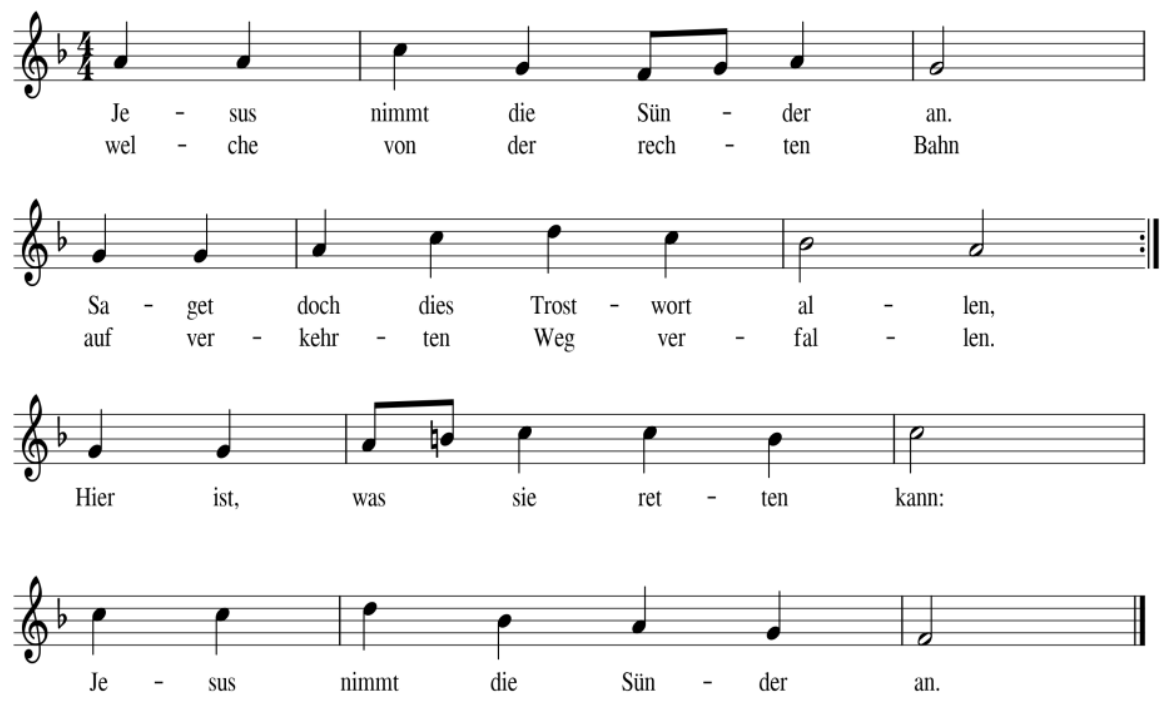

Example 1 Jesus nimmt die Sünder an

(Text: Erdmann Neumeister, Melody: Johann Ulich)

In comparison to that, McGranahan's melody stresses another aspect: The emotion 'joy' is expressed in the text and music by McGranahan (see Example 2). ${ }^{8}$ He composed the

\footnotetext{
${ }^{6}$ Johann Ulich was born in 1634 in Leipzig. He worked at first as an organist in Torgau, then since 1660, as cantor and director of the band (chori musici) in Wittenberg, where he passed away in 1712 (Evangelisches Gesangbuch 1994, No. 957; Thust 2015, 279).

${ }^{7}$ It is included in the Evangelisches Gesangbuch under the number 402.

${ }^{8}$ Sook-Ja Cho compares in Chansyongga (1908) yeongujaryojip [Study on the Chansyongga of 1908] the church hymn contained in the Chansyongga of 1908 (No. 112) with the American source Gospel Hymns of 1894. In Example 2, McGranahan's hymn is printed on the right page, the hymn contained in the Chansyongga of 1908 on the left.
} 
melody in the style of the Gospel songs that was popular at the end of the $19^{\text {th }}$ century and at the beginning of the $20^{\text {th }}$ century in the United States. ${ }^{9}$ This type of the church song goes back to religious mass meetings at that time, which took place especially for unbelievers and neophytes. So, the texts of the Gospel songs are mostly about conversion, repentance through Christ, trust of salvation, and joy in heaven. Melodies consist of major keys, simple harmony, dotted rhythm, and repeated refrains, so that many people can easily sing and learn them. McGranahan's modified text and melody contain these characteristics of the Gospel songs. They are typical for the dotted rhythm in 4/4-time and the triple rhythms in 12/8-time and give the listeners lightness and elation. This way, his hymn does not seem melancholy, although the text mentions "sinful men/Sünder". This is how Neumeister's text was arranged at the end of the $19^{\text {th }}$ century by American composers and was combined with a melody in the style of the then-popular Gospel songs.

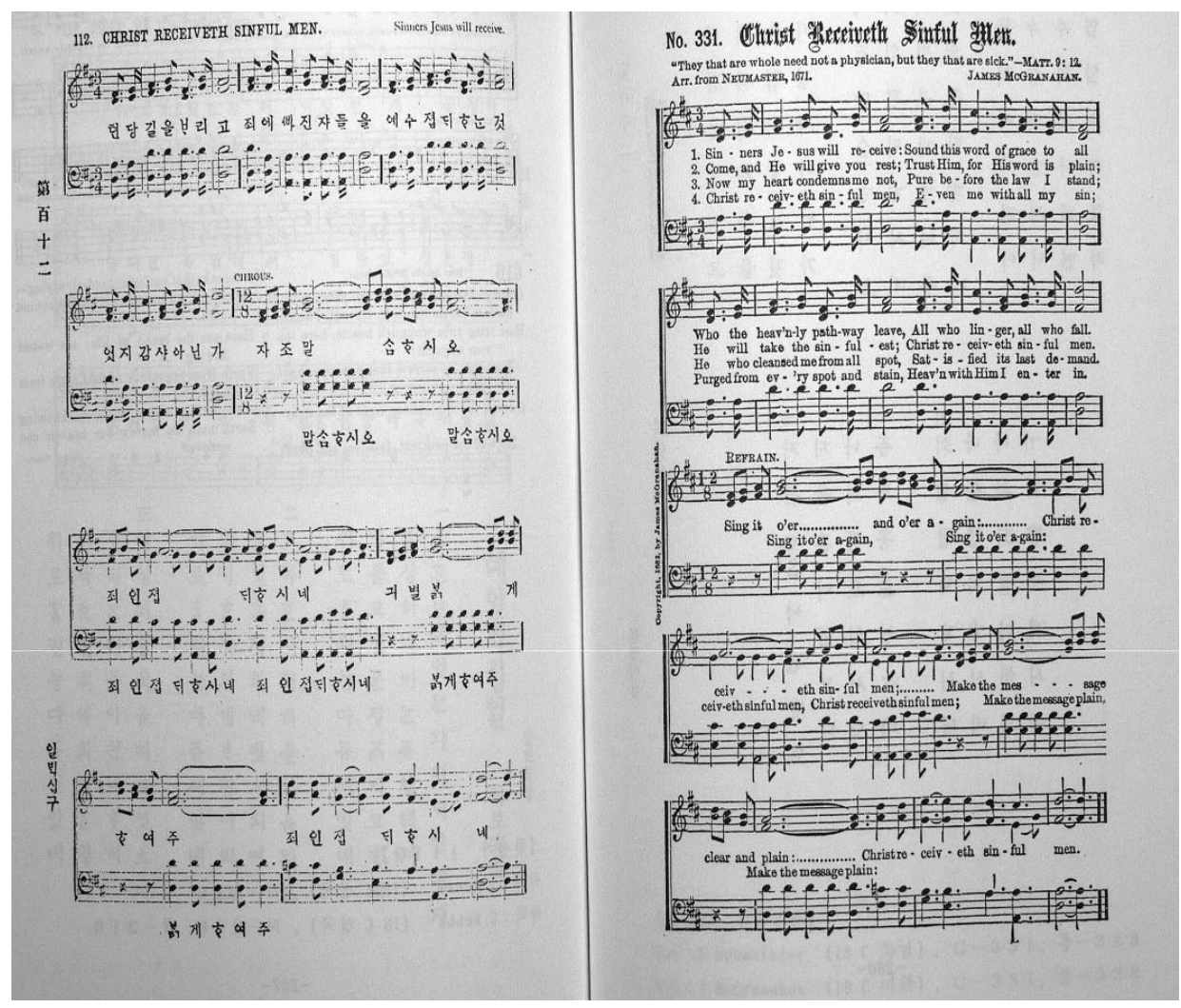

Example 2 쳔성길을 버리고 / Sinners Jesus will receive (Text: Erdmann Neumeister, Melody: James McGranahan), in Sook-Ja Cho, Chansyongga (1908) yeongujaryojip [Study on the Chansyongga of 1908] (Seoul: The Church Music Institute of the Presbyterian College and Theological Seminary, 1995), 258-259. Public Domain.

${ }^{9}$ For the characteristics of the American Gospel songs see Cho 2007, 107; Eskew and Downey 2001, 172; Hong 1988, 261-268; Hong 2000, 160, 168, 191-192, 198, 332-334; Hong 2013, 97-122; Kwak 1997, 44-47. 


\section{ADAPTION BY AMERICAN AND KOREAN HYMNALS}

Since McGranahan's song appeared in his men's choir collection The Gospel Male Choir, vol. 2 of 1883, it is adapted by other hymnals. According to the hymnal website https://hymnary.org/text/sinners_jesus_will_receive, it frequently appeared especially in the 1920s, 1950s, and 1970s in hymnals. It is included in following hymnals: Baptist Hymnals of 1991 (No. 563), of 2008 (No. 471), Hymns of Faith of 1980 (No. 340), Rejoice Hymns of 2011 (No. 340), The Song book of the Salvation Army of 1986 (No. 262), and over 200 other instances. It should still be noted that McGranahan's hymn is not included in the current Lutheran (Evangelical Lutheran Worship, 2006), Methodist (The United Methodist Hymnal, 1989), and Presbyterian Hymnals (The Presbyterian Hymnal, 1990).

American missionaries included McGranahan's hymn in the Korean Protestant Hymnal. It appeared for the first time in the Chansyeongsi of 1898 under the number 60 (Cho 1996, 113); as its source, Gospel Hymns No. 5 of 1887 was used (Cho 2007, 64). The text contained in the Chansyeongsi of 1898 was translated by Annie L. A. Baird ${ }^{10}$ into Korean (Cho 1996, 113). In order to make the translation understandable and singable, Baird modified the order. As an example, the first four lines of the first stanza are compared:

Comparison of the Korean Translation with the English Source

Gospel Hymns of 1894, No. 331

21st Century Hymnal of 2006, No. 512

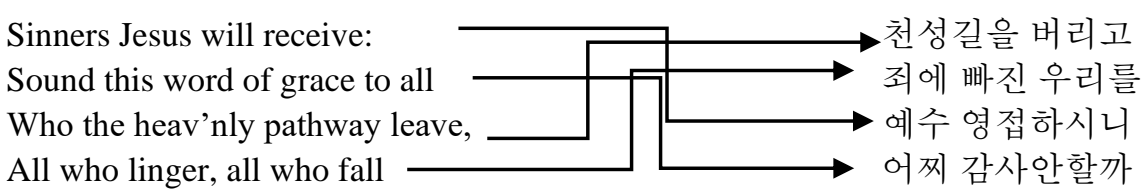

Baird's translation was adopted by the subsequent hymnals; even the current hymnal $21^{\text {st }}$ Century Hymnal of 2006 took it without major discrepancies. ${ }^{11}$ For the Korean hymnal, the arranged text by McGranahan plays a crucial role, although the original text comes from Neumeister. As it is clearly shown in the refrain and the music by McGranahan, the emotion 'joy' and the invitation to pass on the Good News are of prime importance. It is not surprising that, in the $21^{\text {st }}$ Century Hymnal of 2006, the hymn is assigned to the rubric "world mission", while Neumeister had probably not thought of such an accentuation in the writing of his lyrics.

\footnotetext{
${ }^{10}$ Annie Laurie Adams Baird (1864-1916) came as a Northern Presbyterian missionary with her husband William Martyne Baird 1890/1891 [?] to Korea and committed herself to women and children in Korea. Since 1898, she participated in the translation and publication of the hymnals Chansyeongsi and Chansyongga of 1908 as well as the song collection Changajip of 1915 (Cho 2007, 78-79; Mun 2004, 435).

${ }^{11}$ Baird's translation, which appeared at the end of the $19^{\text {th }}$ century, was reproduced in the $21^{\text {st }}$ Century Hymnal of 2006 in the modern orthography. In addition, some old words were improved, so that one can understand them today.
} 


\section{CONCLUSION}

The church hymn Christ Receiveth Sinful Men shows how Neumeister's lyrics were modified by the American Gospel song composer McGranahan. Primarily, Neumeister wrote the lyrics for his Lutheran congregation. It was based on the parables of the lost sheep and of the lost coin, and it was meant to be sung with the congregation after his sermon. In comparison to that, McGranahan considered unbelievers and neophytes in order to mission them. For this purpose, he modified Neumeister's text; actually, Bevan's translation. By modifying it, McGranahan adapted the theme of 'sinners' from the original, but he stressed in his lyrics the emotion 'joy'. Corresponding to this, McGranahan composed a new melody, which contained dotted rhythms and a refrain - characteristics of the Gospel songs at that time.

This new version of McGranahan has an impact on the Korean Hymnal. Since its introduction through American missionaries in 1898, it is still sung today. It was translated by the American missionary Annie Baird, and her translation is still used today, because her translation is easy to sing, with good text flow. She did not translate the English text word-byword, because she knew the differences between the English and Korean languages. By translating Christ Receiveth Sinful Men into Korean, she changed the order. Her style was an example for other American missionaries (Miller 1993, 169-170). So, the Gospel song of McGranahan was quickly spreading through Baird's translation in Korea, and the Korean Christians enjoyed singing it especially during the $20^{\text {th }}$ century. However, most American and Korean Christians do not know about the German original and how this was changed. As this study shows, McGranahan's Gospel song is far from Neumeister' intention, and it is to consider whether it would be legitimate that the adaption can be so different from the original.

\section{REFERENCES}

Cho, S. J., (1995), Chansyongga (1908) yeongujaryojip [Study on the Chansyongga of 1908], The Church Music Institute of the Presbyterian College and Theological Seminary, Seoul.

(1996), Chansongga (1983) haeseol [Comment on the Chansongga of 1983], The Church Music Institute of the Presbyterian College and Theological Seminary, Seoul.

(2007), Hangung gaesingyochansongga yeongunonmunjip [Collection of Studies on the Korean Protestant Hymnal], edited by Jung-Eun Kim, Presbyterian College and Theological Seminary Press, Seoul.

"Christ Receiveth Sinful Men", [Online]. Available: https://hymnary.org/text/sinners_jesus_will_receive [Accessed on 3 January 2020].

Dictionary of Hymnology. Origin and history of Christian hymns and hymnwriters of all ages and nations (1985), Julian, J. (ed.), Second Edition, Vol. 1, Kregel Publications, Grand Rapids/Michigan.

Die Lieder unserer Kirche. Eine Handreichung zum Evangelischen Kirchengesangbuch von Johannes Kulp (= Handbuch zum evangelischen Kirchengesangbuch, Sonderband), (1958), revised and edited by Arno Büchner and Siegfried Fornaçon. Vandenhoeck \& Ruprecht, Göttingen.

Eskew, H. and Downey, J., (2001), "Gospel music. White gospel music", In: Sadie S., (ed.) The New Grove Dictionary of Music and Musicians, Second Edition, Vol. 10, Macmillan et al., London: pp. 172-177.

Evangelical Lutheran Worship. Pew Edition, (2006), 4th Reprint. Minneapolis: Augsburg Fortress.

Evangelisches Gesangbuch. Ausgabe für die Evangelische Kirche in Hessen und Nassau, (1994), edited based on the resolution of Achte Kirchensynode der Evangelischen Kirche in Hessen und Nassau from December 3, 1993, Spener Verlagsbuchhandlung., Frankfurt am Main.

Gospel Hymns Nos. 1 to 6, (1895), Sankey, I. D., Granahan, J. M. and Stebbins, G. C. (eds.), The John Church Co., Cincinnati/Chicago/New York, The Biglow \& Main Co., Chicago/New York..

Hanyeongsaechansongga (Korean-English New Hymnal), (2011), Korean Hymnal Society (ed.), Saengmyeonguimalsseumsa (Lifebook), Seoul.

Hong, J. S., (1988), Gyohoeeumakgaeron [Introduction to Church Music], The Church Music Institute of the Presbyterian College and Theological Seminary, Seoul. 
(2000), Hangung gyohoeeumang sasangsa [The History of the Ideas on the Korean Church Music], The Church Music Institute of the Presbyterian College and Theological Seminary, Seoul.

, (2013), A History of Korean Church Music, translated by Mi-Ock Kim, Presbyterian College and Theological Seminary Press, Seoul.

Kwak, S. S., (1997), "Hangukchansongga, mueosi munjeinga" [Problematic Aspects in the Korean Hymnal], Gidokgyosasang [Christian Thoughts] 41: pp. 44-63.

Liederkunde. Zweiter Teil: Lied 176-394 (= Handbuch zum Evangelischen Kirchengesangbuch III/2), (1990), Stalmann J. and Heinrich, J. (eds.). Vandenhoeck \& Ruprecht, Göttingen.

Mearns, J., (1985), "Bevan, Emma Frances, née Shuttleworth", in Dictionary of Hymnology. Origin and history of Christian hymns and hymnwriters of all ages and nations, Julian, J. (ed.), Second Edition, Vol. 1, p. 139. Kregel Publications, Grand Rapids/Michigan.

Miller, F. S., (1993), "Early Korean Hymnology", in Hangung gyohoeeumang saryojip [Collection of Documentation of the Korean Church Music], Hong, J. S. (ed.), The Church Music Institute of the Presbyterian College and Theological Seminary, Seoul, Vol 2: pp. 169-170.

Moon, Y. T. and Na, J. G., (2012), 21segi chansongga haeseoljip [Comment on the 21st Century Hymnal], Gaonum, Seoul.

Mun, O.B., (2004), Hangung gyohoeeumang suyongsa [Reception of the History of the Korean Church Music], Second edition, Yesolpress, Seoul.

Oh, S., (2015), 21segi chansongga haeseol (A Study of New Century Korean Hymnal), Second Edition, Biblehouse, Gyeonggido/Korea.

Songs of Eternal Life, [1858], translated by Emma F. Bevan, C. F. Hodgson, London.

The Presbyterian Hymnal. Hymns, Psalms, And Spiritual Songs, (1990), Westminster/John Knox Press, Louisville, Kentucky.

The United Methodist Hymnal. Book of United Methodist Worship, (1989), The United Methodist Publishing House, Nashville, Tennessee.

Thust, K.C., (2015), Die Lieder des Evangelischen Gesangbuchs. Band 2: Biblische Gesänge und Glaube - Liebe Hoffnung (EG 270-535), Kommentar zu Entstehung, Text und Musik, Vol. 2, Bärenreiter, Kassel.

Wilhoit, M.R., (2013), "McGranahan, James", In: The Grove Dictionary of American Music, Garrett, C. H. (ed.), Second Edition, Vol. 5, Oxford University Press, New York: pp. 302-303.

\section{CRKVENA HIMNA „HRIST PRIMA GREŠNE LJUDE“: ODNOS SA NEMAČKIM ORIGINALOM I NJEGOVA ADAPTACIJA U AMERIČKIM I KOREANSKIM HIMNARIJUMIMA}

U 19. veku nemačke protestantske himne prevedene su na engleski jezik i pevane su na njegovom jezičkom području. Evangelizacijom Koreje uvedene su zapadne - uključujući neke nemačke - crkvene himne. Međutim, može se primetiti da se u procesu prevođenja pojavljuju sadržajne, kao i jezičke i muzičke razlike između nemačke i koreanske verzije. Ovaj rad ispituje crkvenu himnu „Hrist prima grešne ljude”, koja je bila uključena u korejske pesmarice krajem 19. veka. Ova crkvena himna ima zanimljivu istoriju; njen tekst je poreklom iz Nemačke, dok je muzika poreklom iz Sjedinjenih Država. Rad se bavi pitanjem kombinovanja teksta i muzike i promenama nastalim u njihovom prenošenju. Metodološki, upoređivani su izvori koji su bili relevantni u vreme adaptacije. Međukulturni odnosi između himni drugih zemalja mogu biti zanimljivi ne samo za naučnike koji se bave himnologijom, već i za misiologe i muzikologe, kao i za crkvene muzičare.

Ključne reči: Jesus nimmt die Sünder an (Isus prihvata grešnike), Christ Receiveth Sinful Men (Hrist prima grešne ljude), Erdmann Neumeister, James McGranahan, Evangelisches Gesangbuch of 1993, 21st Century Hymnal of 2006 